\title{
EFFECTS OF FLEXIBILITY AND INTERACTIVITY ON THE PERCEIVED VALUE OF AND SATISFACTION WITH E-COMMERCE (EVIDENCE FROM INDONESIA)
}

\section{UČINCI PRILAGODLJIVOSTI I \\ INTERAKTIVNOSTI NA PERCIPIRANU \\ VRIJEDNOST I ZADOVOLJSTVO \\ ELEKTRONIČKIM TRGOVANJEM (DOKAZI IZ INDONEZIJE)}

\section{Purwanto ${ }^{a}, K_{\text {Kuswandi }}$}

a) Supratman University, Surabaya, INDONESIA, cakpo3r@gmail.com

b) Mahardhika University, Surabaya, INDONESIA

\section{Abstract}

Purpose - The purpose of the present study was to analyze the effect of flexibility and interactivity on perceived utilitarian value and hedonic value, ultimately determining the satisfaction level of e-commerce users.

Design/Methodology/Approach - Data were analyzed by using the Structural Equation Modeling (SEM) with AMOS 18. A sample of e-commerce users were taken by using the incidental sampling technique. A total of 650 respondents participated, forming the sample and the usable size was 415 after the screening process.

Findings and implications - First: flexibility (navigation, comfort, and the substitutability of personal examination) had an effect on utilitarian value, but not hedonic value; second, interactivity (controllability, synchronicity, and bi-directionality) had an effect on utilitarian value and hedonic value; third, perceived value had an effect on satisfaction. E-tailers should allocate their resources appropriately, combining the qualities

\section{Sažetak}

Svrha - Svrha istraživanja jest analizirati učinak prilagodljivosti i interaktivnosti na percipiranu utilitarnu vrijednost i hedonističku vrijednost, a kako bi se u konačnici odredila razina zadovoljstva korisnika elektroničkog trgovanja.

Metodološki pristup - Podaci su analizirani primjenom modeliranja strukturnih jednadžbi (SEM) sa softverom AMOS 18. Korisnici elektroničke trgovine $u$ uzorak su birani slučajnim odabirom. U istraživanju je sudjelovalo ukupno 650 ispitanika, a nakon što su prošli inicijalnu provjeru, 415 upitnika iskorišteno je za analizu.

Rezultati i implikacije - Prvo: prilagodljivost (navigacija, udobnost, zamjenjivost osobnog ispitivanja) imaju učinak na utilitarnu, ali ne i na hedonističku vrijednost; drugo: interaktivnost (mogućnost kontroliranja, usklađenost i dvosmjernost) imaju učinak na utilitarnu vrijednost i na hedonističku vrijednost; treće, perci- 
of utilitarian and hedonic values on their website proportionally (powerfully and stylishly) well to improve the overall perceived value. When a company has limited resources, the trade-off of utilitarian and hedonic values should be well-considered. For example, adding more interesting and easy-to-understand features, such as a more flexible and interactive live chat, would make it easier for consumers to select products/services as if performing off-line transactions.

Limitations - Despite the justification in the literature for using ethnicity- and region-based samples in Indonesia for Internet-related studies, those samples may not reflect the actual overall population of online consumers worldwide.

Originality - This paper develops an interactivity model by adding the flexibility construct to increase the perceived value in e-commerce supported by the latest literature and some important recommendations for further research.

Keywords - Flexibility, interactivity, utilitarian value, hedonic value, satisfaction pirana vrijednost ima učinak na zadovoljstvo. Elektroničke bi prodavaonice trebale usmjeriti resurse na odgovarajući način kombinirajući podjednako dobro kvalitete utilitarnih i hedonističkih vrijednosti na svojim internetskim stranicama (snažno i sa stilom) kako bi poboljšale ukupnu percipiranu vrijednost. Kad poduzeće ima ograničene resurse, treba razmatrati kompromis između utilitarnih i hedonističkih vrijednosti. Primjerice, dodavanjem zanimljivijih i lako razumljivih značajki, poput prilagodljivijeg i interaktivnog chata uživo, pojednostavnilo bi potrošačima odabir proizvoda/usluga kao kod provođenja off-line transakcija.

Ograničenja - Usprkos opravdanosti koju literatura navodi za korištenje uzoraka na temelju etničke pripadnosti i regije u Indoneziji, za istraživanja vezana uz internet ti uzorci ne moraju odražavati stvarnu ukupnu populaciju on-line potrošača diljem svijeta.

Doprinos - Ovaj rad razvija model interaktivnosti dodavanjem konstrukta prilagodljivosti kako bi se povećala percipirana vrijednost u elektroničkom trgovanju, poduprt najnovijom literaturom i nekim važnim preporukama za buduća istraživanja.

Ključne riječi - prilagodljivost, interaktivnost, utilitarna vrijednost, hedonistička vrijednost, zadovoljstvo 


\section{INTRODUCTION}

The development of the Internet usage has changed the patterns of people's effective marketing communications and online transactions. Research conducted in 12 major cities in Indonesia from mid-2014 to January 2015, on respondents in the segments starting from 18 years of age, managed to obtain important findings. The estimated total market value of e-commerce in Indonesia amounted to USD 8 billion in 2014 and will continue to increase to USD 24 billion in 2016 (Indonesian E-commerce Association, 2016). Application-equipped smart phones are currently capable of accessing an almost unlimited selection of products and services, comparing prices, selecting types of items, and performing real-time transactions (Park, Jun \& Lee, 2015; Wang, Malthouse \& Krishnamurthi, 2015; Pantano \& Priporas, 2016; Yoo, Yunjung \& Jung, 2010). Thus, an understanding of the target audience as purchasers via e-commerce should be further improved by adding more complete features (Overby \& Lee, 2006). Additionally, the user interface and website design should emphasize the content, rather than focus on excessive advertising (Burke, 1997; Crockett, 2000; Mitchell, 2000; Overby \& Lee, 2006). Interaction and flexibility constitute the best means to improve e-commerce (Childers, Carr, Peck \& Carson, 2001; Overby \& Lee, 2006). Increased interaction and flexibility play an important role in shifting the persuasive transmission method of the seller's message to the communicative one reciprocally via smart phones/ computers (Yoo et al., 2010). Interactivity is a two-way communication capable of improving the quality of the message (Berthon, Pitt \& Watson, 1996). In the e-commerce booking environment, customer - service provider interactivity and flexibility are the most effective means to transact (Childers et al., 2001; Yoo et al., 2010).

Booking products or services online provides an easy and time-saving experience because there is no geographical border. On the contrary, since the customer does not deal directly with the operator in the process of online booking, the customer often encounters difficulties obtaining an immediate response from the e-tailer (Yoo et al., 2010). E-tailers have more disadvantages when interacting with customers than when transacting off-line. Various disadvantages of transacting online have been recognized by many researchers as the factor differentiating off-line services from online ones, especially for products/services requiring more detailed information (Pitta, Franzak \& Fowler, 2006; Yoo et al., 2010). Despite the identification by previous studies of the disadvantages of online transactions, these studies have not fully captured the idea as to how e-commerce can resemble off-line transactions. Thus, flexible features are important to deal with the disadvantages of online transactions. This is not to mention the issues such as the honesty of the service provider/vendor (Groß, 2016; vor dem Esche \& Hennig-Thurau, 2014; San-Martín \& López, 2013) - as an important consideration for consumers to use online transactions - or cyber crime, items not conforming to their specifications, defective products, counterfeit products, and undelivered goods (Taichon \& Sara, 2016; Yang, Chen \& Wei, 2015; Sohn, 2014; Ferri, Grifoni \& Guzzo, 2013; Banerjee \& Dholakia, 2013; Büttner \& Göritz, 2007). Therefore, e-tailers need to respond to customers' questions and demands posted on the website while also being responsive with regard to improving mutual communication as a proof that the service provider is a trusted one (Miles, 1992; Büttner \& Göritz, 2007; Yoo et al., 2010).

Online interactions cover all computer- or smartphone-mediated human interactions (Stromer-Galley, 2000; Pantano \& Priporas, 2016). Yadav and Varadarajan (2005), Childers and others (2001), and Yoo and others (2010) argued that high flexibility and interactivity are useful for customers' better decision making, hence, they may be used to improve relationship marketing and marketing strategy. In order to address the lack of interactive face-to-face services in e-commerce, e-tailers increase interactivity and flexibility by facilitating a variety of commu- 


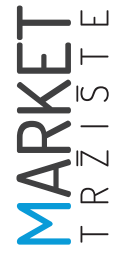

nication features that include bulletin boards, real-time conversation, and search engines, and offering various types of services in addition to delivery, such as ordering food, goods delivery, and others. E-tailers' improved flexibility and interactivity offers such benefits as facilitating communication, information, image manipulation, and entertainment for customers (Yoo et al., 2010; Fiore \& Kim 2007; Fiore, Kim \& Lee, 2005; Childers et al., 2001).

The facilitation of interactivity and flexibility features on smart phone applications aims to increase customers' perceived value and, ultimately, satisfy and retain customers (Gao, Waechter \& Bai, 2015; Kim, Li \& Kim, 2015; Haught, Wei, Xuerui \& Zhang, 2014; Yoo et al., 2010). However, there are still many customers complaining about everything - from the user interface to the overly complicated website to excessive emphasis on advertising at the expense of website content (Burke, 1997; Crockett, 2000; Mitchell, 2000). These factors are symptoms that may be important, but the more likely cause of complaints is a lack of clarification of which consumers constitute target audience. Cowles, Kiecker and Little (2002) suggested that research of e-commerce should consider the value consumers desire to obtain from the media usage since consumers choose and return to those retailers that offer superior benefits set by consumers (Woodruff, 1997). E-tailers should design and ultimately offer the most attractive benefits for e-customers. Despite the huge development of e-commerce in the process of creating value for customers through flexibility and interactivity, little attention has been paid to the empirical literature review. This is particularly true with regard to the issues of trust, ease provided by the e-tailer, detailed description of product or service with more complex characteristics; thus, the concept of flexibility and interactivity is actually needed by both sides. In addition, there is no theoretical certainty of how the concept of interactivity and flexibility in the context of online shopping affects perceived value and satisfaction. The main objective of the present study was to analyze the effect of interactivity and flexibility on perceived value and satisfaction level of e-customers. This study contributes to the literature by defining interactivity and flexibility, utilitarian value, and hedonic value in the online context (Chituri, Rajagopal \& Vijay, 2008; Childers et al., 2001; Yoo et al., 2010). Additionally, the present study fills the gap in the literature left by previous investigators with regard to interactivity and flexibility (Childers et al., 2001; Yoo et al., 2010). An efficient measurement of the level of interactivity and flexibility in association with user controllability, responsibility, real-time participants and interchangeability has not received the full attention of many researchers. A clear understanding of flexibility and interactivity would be useful for e-tailing researchers and practitioners alike. E-tailers would be able to find more efficient and effective ways to improve flexibility and e-interactivity of their website by identifying the important factors of e-interactivity and flexibility that affect the benefits of post-consumption emotion and consumer satisfaction.

\section{THEORETICAL BACKGROUND AND HYPOTHESIS DEVELOPMENT}

\subsection{Interactivity}

The interactive nature of the Internet and the web offers various opportunities to improve the efficiency of online shopping behavior by increasing the availability of product information, the possibility of a direct multi-attribute comparison and reduction of search costs (Childers et al., 2001; Bakos, 1997; Alba et al., 1997). Interactivity is defined as communication between users and computer technology regardless of space and time, in which users can freely modify the form and content in real timer (Yoo et al., 2010; Coyle \& Thorson, 2001; Ha \& James, 1998; Steuer, 1992). In general, interactivity has three dimensions: controllability, synchronicity, 
and bi-directionality (Liu, 2003; Yoo et al., 2010). Zeithaml, Parasuraman and Malhotra (2002) describe interactivity as website users being capable of communicating, finding information and transacting via the website, based on the theory of cybernetics rooted in media interaction regarding the use of information and feedback (Stromer-Galley, 2000; Yoo et al., 2010). Furthermore, according to Wiener (1948), interactivity serves only as feedback in the media. Therefore, Van Dijk (1999) and Yoo and others (2010) concluded that computer media interaction has a low level of interactivity. More specifically, interactivity consists of user-machine interaction, user-user interaction, and user-message interaction (Yoo et al., 2010; Cho \& Leckenby, 1997). User interaction is based on inter-individual communication. When communication is mediated by information technology, user-user interaction will become more interactive (Ha \& James, 1998; Yoo et al., 2010).

The features of a website include a bulletin board, an e-mail link, a chat room, a search engine, feedback forms, etc. (Massey \& Levy, 1999; McMillan, 1998; Yoo et al., 2010). These features illustrate that the website has a high level of interactivity. For example, a feedback form and an e-mail boost the level of perceived synchronicity as users easily search for the information they need (Ghose \& Dou, 1998). Similarly, search engines increase user controllability, making it easier to find relevant information (Hoffman \& Novak, 1996).

In order to measure the level of flexibility and interactivity efficiently, many researchers pay attention to the multi-dimensionality of interactivity in relation to user controllability, responsibility, real-time participants, navigation, ease of use, convenience, sub-experience, usefulness, and interchangeability (Yoo et al., 2010; Childers et al., 2001; Rafaeli, 1988; Rice, 1984; Jensen, 1998; Steuer, 1992). Straubhaar and LaRose (1996) define interactivity as a situation of real-time communication, role interchangeability, live chat and user controllability.
Yadav and Varadarajan (2005) and McMillan (2005) define interactivity of e-commerce as computer-mediated communication perceived by each communication entity which is (a) twoway, (b) timely, (c) mutually controlling, and (d) responsive. Furthermore, Van Dijk (1999) added the importance of the following three components by arguing that the two-way communication, as well a high level of synchronicity and controllability are needed to achieve the highest level of interactivity.

Thus, based on previous research, interactivity can be divided into three elements: controllability, synchronicity, and bi-directionality. First, controllability is defined as the degree to which the communicant manipulates the content, timing, and sequence of communications (Park et al., 2015; Yadav \& Varadarajan, 2005; Fortin \& Dholakia, 2005; McMillan \& Hwang, 2002; Coyle \& Thorson, 2001). Research by Guedj, Hagen, Hopgood, Tucker and Duce (1980) describes interactivity as a style of control. In addition, Ariely (2000) defines interactivity as the level of control. Second, synchronicity refers to the speed of communication and response that facilitates communication (McMillan, 2005; Coyle \& Thorson, 2001; Novak, Hoffman \& Yung, 2000; Hoffman \& Novak, 1996). Third, two-way communication means that the roles of the sender and recipient of the message are interchangeable. Bretz (1983) discerns bi-directionality as a two-way communication. Additionally, Pavlik (1998) suggests that interactivity means two-way communication between the source and the receiver or, more broadly, multi-directional communication between a number of sources and the recipient. The concept of bi-directionality is in accordance with Zack (1993), who outlines the exchange of information, mutuality and closeness. The concept of equality of information is also based on bi-directionality. Hanssen, Jankowski and Reinier (1996) focus on the equality between the participants and functional environment. Even if interactivity involves controllability, synchronicity, and bi-directionality, the three dimensions are interrelated (Liu, 2003). 


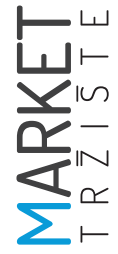

\subsection{Flexibility}

This framework describes the attitude towards the use of a form of online shopping by postulating three antecedents: use of new media, ease of use of new media, and comfort of use of new media. However, what would determine a communicative environment for it to be considered "useful", "easy to use", and or "fun"? Therefore, the concept of flexibility is important in addressing all these (Childers et al., 2001). Alba and others (1997) state that the users of new media, in this case consumers, conduct online transactions using the latest technology. Consumers are looking for the benefits of online shopping compared to offline shopping. Among these benefits are the flexibility provided by the media to access and control the nature of product information, 24-hour media comfort, and multiple-location accessibility (Hoffman \& Novak, 1996; Alba et al., 1997).

Flexibility in online transactions is provided by navigation, comfort, and substitutability of personal examination (Hoffman \& Novak, 1996; Hofacker, 2001; Alba et al., 1997; Rosen \& Howard, 2000). Furthermore, Hoffman and Novak (1996) suggest that navigation in online media is that in which users are given the freedom and the instructions to make applications for real-time transactions automatically. Lynch and Ariely (2000) found that when information on the quality of the product is obtained easily via navigation, consumers are less sensitive to price and even buy more expensive products. Navigation is capable of efficiently reducing the cost of search for the product to be bought (Hoque \& Lohse, 1999). Thus, the structure of the online environment can provide information on the location of the sites offering the products that consumers desire with an adequate and easy-to-understand layout (Titus \& Everett, 1995; Weisman, 1981; Evans, Skorpanich Garling, Bryant \& Bresolin, 1984). Thus, it is expected that people who have a greater desire for choice of alternative forms of navigation would perceive the shopping process or the media ease of use as being more profitable.
Perceived comfort is that in which users can make real-time transaction anytime and anywhere 24 hours a day, 7 days a week (Hofacker, 2001). This flexibility provides users with comfort. The users perceiving online environment as offering greater comfort are more likely to consider the new media as both "useful" and "easy to use" (Davis, Bagozzi \& Warshaw, 1992; Igbaria, Schiffman \& Wieckowski, 1994; Childers et al., 2001). The perceived comfort of media facilitates the fulfillment of a shopping task (thus making it more useful) and also makes the shopping process (ease of use) more attractive. In addition, reduced frustration can reduce psychological costs of shopping and will make the experience of interactive shopping more flexible and fun. Flexibility also provides e-commerce users with the benefits of substitutability of personal examination. The technology in e-commerce allows users to perceive the replacement of the ease of finding a variety of products on the website (Peck \& Childers, 2000). Furthermore, Childers and others (2001) argue that online shopping is perceived as being the same as offline shopping, in which consumers are capable of examining products carefully (e.g., texture, hardness, temperature, color, size, and weight).

\subsection{Antecedents: utilitarian value and hedonic value}

Several studies showed that interactivity and flexibility have an effect on trust (Yoo et al., 2010; Merrilees \& Fry, 2003). In addition, interactivity and flexibility can create values (Stewart \& Pavlou, 2002; Childers et al., 2001). E-commerce on the website serves to provide a wide range of information and promotions for products and services that are taken into consideration in decision-making (Yoo et al., 2010). Furthermore, according to Yoo and others (2010), the features of a website can improve customers' decision quality and confidence in the product. Childers and others (2001) and Teo, Oh, Liu and Wei (2003) argue that perceived value of the product or service can be influenced by interactivity and flexibility. For example, Yoo and 
others (2010) and Kim and LaRose (2004) assert that interactivity and flexibility can influence the perception of price, product quality, and ease of online use of a website as value for the customer. Since interactivity and flexibility distinguish the quality of a web for e-commerce $(\mathrm{Wu}, 2005)$, it is reasonable to analyze the effects of interactivity and flexibility on the perceived value in the process of e-commerce.

Teo and others (2003) argue that the attribute of interactivity has a significant effect on perceived value. Zeithaml (1988) and Sheth, Newman and Gross (1991) confirm that business success requires a lot of consumer values of products or services. Value constitutes another important element in managing relationships with customers. Consumer value is a comparison of what is received and what is expected (McDougall \& Levesque, 2000; Woodruff, 1997; Zeithaml, 1988). Since the definition of value varies according to its context (Babin, Darden \& Griffin, 1994; Dodds, Monroe \& Grewal, 1991; Holbrook, 2005), the researchers have conceptualized value as the outcome of consumption experience.

An approach to utilitarian value alone is inadequate to explain consumer's perceived value thoroughly. Thus, the approach to examining consumption value in the present study was that of utilitarian and hedonic values. Utilitarian value is defined as a comprehensive evaluation (i.e. a decision) of the functional benefits and sacrifice (Hirschman \& Holbrook, 1982; Babin et al., 1994; Childers et al., 2001). Utilitarian value is relevant to the use of task-specific online shopping, such as consideration, for the purchase (considering the aspects of products, services and prices prior to the actual purchase) (Hoffman \& Novak, 1996). Although this concept is the same as the active source of the extrinsic value of Internet shopping as identified by Mathwick, Malhotra and Rigdon (2001), the researchers of the present study believed in the importance of further differentiating utilitarian value as something unique and different from hedonic value.
Utilitarian value incorporates more cognitive aspects of attitudes, such as economic value for money (Zeithaml, 1988) and the value judgment of convenience and time saving (Jarvenpaa \& Todd, 1997; Teo et al., 2003). For example, a shopper can shop online because of the ease of finding and comparing vendors, evaluating the price/quality ratio, and saving time and psychological resources (Grewal, Gopalkridhman, Krishnan \& Sharma, 2003; Mathwick et al., 2001). Hedonic value is defined as a comprehensive evaluation (i.e. decision) of experiential benefits and sacrifice, such as entertainment and escapism.

Consumers often shop for the sake of appreciation for the experience, not only to complete the task (Babin et al., 1994). Various dimensions of hedonic value have been widely investigated in the literature of in-store shopping (see Babin \& Attaway, 2000; Darden \& Reynolds, 1971; Overby \& Lee, 2006; Yoo et al., 2010) and were recognized as an essential element of online shopping (Burke, 1999; Hoffman \& Novak, 1996). Interactivity and flexibility are also key aspects affecting consumers' utilitarian value (Yoo et al., 2010). According to Novak and others (2000) and Childers and others (2001), consumers evaluate e-commerce websites negatively when they experience long-waiting times, or find the website to be complicated and lacking flexibility. Consumers were also found to require frequent website updating to provide them with the latest information and to improve the positivity of their experience (Geissler, 2001). Lastly, improved bi-directionality was found to increase perceived quality (Berthon et al., 1996). Based on the literature, the following hypotheses are proposed:

Hypothesis 1a: Flexibility of e-commerce websites will have a significant effect on perceived utilitarian value.

Hypothesis 1b: Interactivity of e-commerce websites will have a significant effect on perceived utilitarian value.

Coyle and Thorson (2001), Liu and Shrum (2002), and Sundar and Kim (2005) argue that interactivity and flexibility have an effect on perceived 
hedonic value. As stated earlier, consumers are eager to obtain hedonic and utilitarian values from their shopping experience (Yoo et al., 2010). Thus, consumers expect an e-commerce website to be fun and exciting (Parsons, 2002). Literature indicates that interactivity increases values by providing consumers with the flow of experience and pleasure (Hoffman \& Novak, 1996; Sicilia, Ruiz \& Munuera, 2005; Chliders et al., 2001; Yoo et al., 2010). Thus, the following two hypotheses are proposed:

Hypothesis 2a: Flexibility of e-commerce websites will have a significant effect on perceived hedonic value.

Hypothesis 2b: Interactivity of e-commerce websites will have a significant effect on perceived hedonic value.

\subsection{Satisfaction}

The outcome of the post-consumption evaluation is that a customer may be satisfied, dissatisfied, angry, or happy (Mowen \& Minor, 2002). Kotler and Kevin (2009) argue that satisfaction is one's feeling of delight or disappointment that arises after comparing the perceived performance (result) of a product against its expected performance.

Using the expectancy disconfirmation model, Oliver (1980) suggests that satisfaction is the result of comparison of a customer's pre-consumption expectations of a product and the actual performance of the product. The level of satisfaction is influenced by the level of consumer value (Auh \& Johnson, 2005; Ravald \& Grönroos, 1996). Zeithaml (1988) suggests that the perceived value the consumers receive may satisfy or dissatisfy them. The effects of perceived value on satisfaction in the context of services have been found in empirical studies. Furthermore, McDougall and Levesque (2000) argue that customer satisfaction in the service industry is primarily affected by perceived value. According to Chitturi and others (2008), products that meet the expected utilitarian value will increase satisfaction. According to Yoo and others (2010), e-commerce, in which hedonic value has an effect on satisfaction and is supported by an interactive relationship between the provider and purchase, makes customers experience an intimate relationship, leading e-commerce users to be increasingly delighted. Therefore, the researchers of the present study seek to expand the effects of perceived utilitarian and hedonic) value on satisfaction in the context of e-commerce. Thus, the researchers propose the following hypotheses. The conceptual framework describing the hypotheses is shown in Figure 1.

Hypothesis 3a: Perceived utilitarian value will have a significant effect on satisfaction with e-commerce.

Hypothesis 3b: Perceived hedonic value will have a significant effect on satisfaction with e-commerce.

FIGURE 1: Conceptual model of the proposed framework

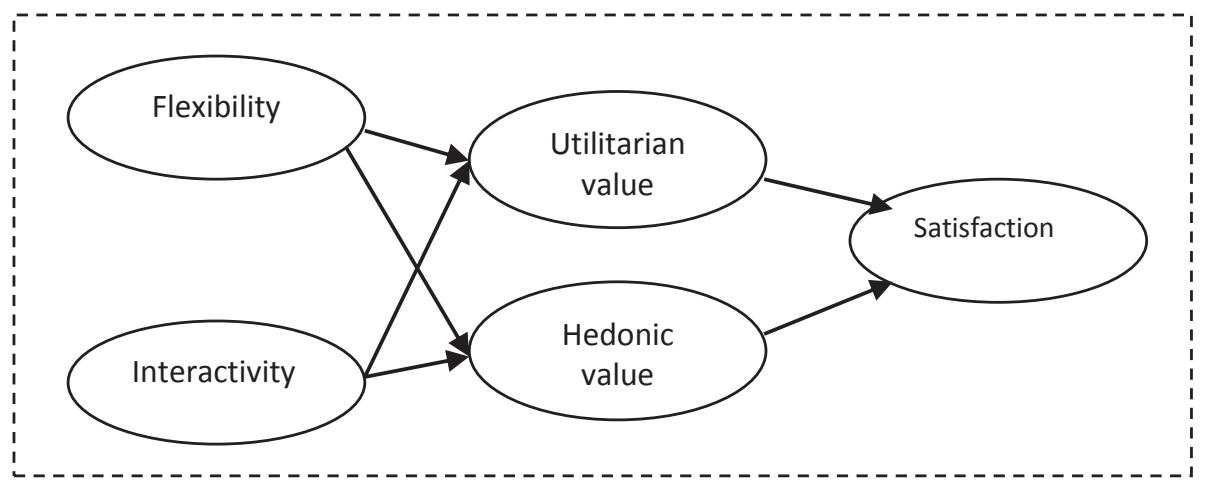




\section{METHODOLOGY}

\subsection{Sample and data collection}

The sample in the present study consisted of consumers who had had at least one previous experience with online shopping. Swinyard and Smith (2003) and McKnight, Choudhury and Kacmar (2002) argue that online shoppers are likely to be younger, having higher levels of education than ordinary consumers, relatively wealthy, and experienced with the Internet. The questionnaire was given to the website visitors as respondents, selected by using the incidental sampling method. The selected respondents were asked to fill out the questionnaire relating to the e-retailer they recently shopped at. They were subsequently asked to indicate the extent to which each statement characterized their thoughts and perceptions, as well as the way they interact online. The survey was carried out over several months and resulted in 415 usable responses. All the items of the questionnaire were measured on a 5-point Likert scale, ranging from "strongly disagree" to "strongly agree". Since the population was limited to the customers with at least one online shopping experience, the first part of the questionnaire was designed to screen those participants as respondents. Then, participants were asked to recall the online shopping experience that they could recall clearly. To ensure that their description was clear, they were asked to write down the product/service purchased and the website on which they purchased it. The profile of the sample is presented in Table 1. The questionnaire consisted of the following five parts: (1) Interactivity, (2) flexibility, (3) consumer's perceived (utilitarian and hedonic) value, and (4) satisfaction.

TABLE 1: Sample profile $(N=415)$

\begin{tabular}{|l|c|c|c|c|}
\hline & Frequency & Percentage & Mean & $\begin{array}{c}\text { Standard } \\
\text { Deviation }\end{array}$ \\
\hline Age & & & 23.58 & 5.51 \\
\hline Gender & & & & \\
\hline Male & 185 & 44.58 & & \\
\hline Female & 199 & 47.95 & & \\
\hline No answer & & 7.47 & & \\
\hline Ethnic background & 218 & 52.53 & & \\
\hline Chinese & 197 & 47.47 & & \\
\hline Indigeneous & & & & \\
\hline Geographic background & 112 & 26.99 & & \\
\hline Megapolitan & 138 & 33.25 & & \\
\hline Metropolitan & 165 & 39.76 & & \\
\hline Small City & & & & \\
\hline Online shopping frequency & 109 & 26.27 & & \\
\hline Less than once a month & 198 & 47.71 & & \\
\hline 1-4 times a month & 68 & 16.39 & & \\
\hline More than once a week & 15 & 3.61 & & \\
\hline Once a day & 21 & 5.06 & & \\
\hline More than once a day & 4 & 0.96 & & \\
\hline No answer & & & & \\
\hline Online searching frequency & 76 & 18.32 & & \\
\hline Less than once a month & 269 & 64.82 & & \\
\hline 1-4 times pa month & 45 & 10.84 & & \\
\hline More than once a week & 15 & 3.61 & & \\
\hline Once a day & 10 & 2.41 & & \\
\hline More than once a day & 397 & 95.67 & & \\
\hline Types purchased & 18 & 4.33 & & \\
\hline Products & & & & \\
\hline Services & & & & \\
\hline Souce reschesuts & & & \\
\hline
\end{tabular}

Source: research results 


\subsection{Measures}

Measures used in the present study were adopted from several previous studies. The flexibility scale was developed from previous researchers (Childers et al., 2001; Bollen \& Long, 1993; Byrne, 1998; Hoffman \& Novak, 1996; Lynch \& Ariely, 2000; Rosen \& Howard, 2000) and consisted of nine items. The interactivity scale was also developed from previous researchers using ten items (Liu, 2003; Yoo et al., 2010). The scale of perceived value was adopted from previously published studies (To, Chechen \& Lin, 2007; Overby \& Lee, 2006; Babin et al., 1994; Hirschman, 1986; Maddox, 1982; Unger \& Kernan, 1983; Zeithaml, 1988) and consisted of three items. The scale measuring satisfaction containing three items was adopted from Yoo and others (2010) and Eroglu and Machliet (1990), see Table 2.

TABLE 2: Measurement scales and summary statistics

\begin{tabular}{|c|c|c|c|}
\hline Item & Mean & SD & A \\
\hline Flexibility ( 1 = strongly disagree to 5 = strongly agree $)$ & & & 0.791 \\
\hline I am free to browse product information in real time on this website & 3.615 & 1.202 & \\
\hline The ease of product search makes it insensitive to price & 3.207 & 1.190 & \\
\hline A clear map makes me feel at home browsing items & 4.005 & 1.458 & \\
\hline A comfortable environment makes me feel at home browsing items for 24 hours & 3.831 & 1.416 & \\
\hline A comfortable environment increases efficient browsing & 4.507 & 1.411 & \\
\hline A comfortable environment reduces the pressure of frustration & 3.607 & 1.364 & \\
\hline A comfortable environment reduces the psychological costs & 3.704 & 1.685 & \\
\hline Online shopping feels like traditional store shopping environment & 3.129 & 1.820 & \\
\hline Shopping online enables a direct check of the desired item & 4.711 & 1.780 & \\
\hline Interactivity (1 = strongly disagree to 5 = strongly agree) & & & 0.852 \\
\hline I find this website has a lot of control & 4.359 & 1.735 & \\
\hline This website provides freedom in accordance with what I want to find & 3.772 & 1.881 & \\
\hline I found interesting experience during browsing & 3.004 & 1.850 & \\
\hline This website has speed in processing my order & 4.236 & 1.968 & \\
\hline This website provides information quickly & 4.311 & 1.175 & \\
\hline The website was very slow to respond to my request & 4.585 & 1.181 & \\
\hline The website was very effective in responding to visitors' feedback & 3.897 & 1.194 & \\
\hline This website provides a two-way communication facility & 4.825 & 1.194 & \\
\hline The website was very slow to respond to my feedback & 3.798 & 1.194 & \\
\hline This website provides an opportunity of back comment & 4.767 & 1.210 & \\
\hline Utilitarian value ( $1=$ strongly disagree to $5=$ strongly agree) & & & 0.734 \\
\hline I shop at this website only for what I need & 4.587 & 1.039 & \\
\hline I shop at the website to find what I am searching for & 3.528 & 1.074 & \\
\hline I do not find what I need & 5.886 & 1.115 & \\
\hline The item I ordered was delivered timely & 4.694 & 1.091 & \\
\hline The item I ordered was in accordance with specification & 5.803 & 1.237 & \\
\hline Hedonic value ( $1=$ strongly disagree to $5=$ strongly agree) & & & 0.780 \\
\hline Shopping at this website was very pleasant & 4.893 & 1.293 & \\
\hline I can use this website to kill boredom & 5.841 & 1.295 & \\
\hline I can use this website to spend my spare time & 5.685 & 1.299 & \\
\hline I really enjoy the new products offered by this website & 4.736 & 1.300 & \\
\hline Shopping on this website was really not exciting & 4.737 & 1.364 & \\
\hline Satisfaction ( 1 = strongly disagree to 5 = strongly agree) & & & 0.711 \\
\hline Overall e-commerce shopping experience was satisfying & 3.919 & 0.039 & \\
\hline Overall e-commerce shopping experience was exciting & 2.968 & 0.074 & \\
\hline Overall e-commerce shopping experience was favorable & 3.634 & 0.115 & \\
\hline
\end{tabular}




\subsection{Confirmatory factor analysis (CFA)}

Data were analyzed using the structural equation modeling (SEM) with AMOS 18.0 in order to evaluate the fit of the model (Figure 2). SEM is suitable for the present study because the proposed relationships can be analyzed simultaneously (Hair, Anderson, Tatham \& Black, 2010). Anderson and Gerbing (1988) and Hair and others (2010) recommend the procedure with two stages of analysis: first, we test for the adequacy of each scale consisting of many items in capturing each construct described in the previous measures. Residuals and scales showed satisfactory unidimensionality. All items showed a significant standard loading, implying a convergent validity (see Table 3). Each construct had construct reliability above 0.70 , thus showing an internal consistency or being reliable. In addition, the average variance extracted (AVE) ranged from 0.71 to 0.85 , indicating that each construct had a good discriminant validity or that the variance captured by the construct was greater than that caused by errors in measurement (Fornell \& Larcker, 1981).
Second, the fit of the hypothesized models were tested. The first model showed a goodness of fit index (GOF) which was not in accordance with that recommended $\left(\chi^{2} / \mathrm{df}=4.135, \mathrm{GFI}=0.78, \mathrm{AGFI}\right.$ $=0.75, \mathrm{TLI}=0.81, \mathrm{CFI}=0.83, \mathrm{RMSEA}=0.08)$. Thus, a modification of the model was required (Min \& Mentzer, 2004; Hair et al., 2010; Anderson \& Gerbing, 1988). Results of the second measurement as the process of model modification showed a reasonable fit. Given no single recommended measure of fit for the SEM, the overall fit was estimated based on various indices (Yoo et al., 2010). Empirical estimates for the research model are shown in Table 4. The value of $\chi^{2} / d f$ for the model is 2.135 , which is below the generally desired cutoff value of 3.0 (Segars \& Grover, 1993). The results showed $\chi^{2} / \mathrm{df}=2.135, \mathrm{GFI}=0.907, \mathrm{AGFI}=0.903, \mathrm{TLI}$ $=0.921, \mathrm{CFI}=0.927$, RMSEA $=0.074$, all of which are in accordance with that recommended in the fit model; thus, these results indicate that the data fit the conceptual model of the researcher (Hair et al., 2010; Browne \& Cudeck, 1993).

The researchers did not test for common method variance, as suggested by literature (Podsa-

TABLE 3: Correlations among constructs and square roots of AVE

\begin{tabular}{|l|c|c|c|c|c|}
\hline & Flexibility & Interactivity & $\begin{array}{c}\text { Utilitarian } \\
\text { value }\end{array}$ & $\begin{array}{c}\text { Hedonic } \\
\text { value }\end{array}$ & Satisfaction \\
\hline Flexibility & 0.791 & & & & \\
\hline Interactivity & 0.241 & 0.852 & & & \\
\hline Utilitarian value & -0.021 & 0.111 & 0.734 & & \\
\hline Hedonic value & 0.222 & 0.111 & 0.004 & 0.780 & \\
\hline Satisfaction & 0.251 & 0.080 & -0.140 & 0.311 & 0.711 \\
\hline
\end{tabular}

TABLE 4: Model fit

\begin{tabular}{|l|c|c|}
\hline Goodness of fit indices & Fit guidelines & Proposed model \\
\hline$\chi^{2} / \mathrm{df}$ & - & 213.594 \\
\hline Probability (P) & $\geq 0.05$ & 0.022 \\
\hline CMIN\DF & $\leq 2$ & 1.227 \\
\hline Goodness of fit index (GFI) & $\geq 0.90$ & 0.907 \\
\hline Adjusted goodness of fit index (AGFI) & $\geq 0.90$ & 0.903 \\
\hline RMSEA & $\leq 0.08$ & 0.094 \\
\hline TLI & $\geq 0.95$ & 0.921 \\
\hline CFI & $\geq 0.95$ & 0.927 \\
\hline
\end{tabular}

Source of data: Results of data processing using SEM 
koff, MacKenzie \& Podsakoff, 2012). According to Spector (1987), there is little evidence that method variance is a problem which could bias the results of a study. So, he argues, the issue of common methods is in fact a myth. Despite the finding of evidence of method effects, the study by former researchers concluded that it did not significantly affect the parameters of the structural relations model (Williams \& Anderson, 1994). In addition, as questioned by Reio (2010), if a study should make use of multi-method (as a solution to a single method), then quantitative exploratory studies within organizations, where considerable time and costs can seriously limit researchers' choice of data collection methods, can be underestimated as a valid theory-building research.

Since the present study is a behavioral one, inseparable from the potential common method bias / common method variance caused by the use of single-source and self-reported measuring instruments, the potential common method bias was reduced by not showing the research title and variable names in the questionnaire (Kammeyer-Mueller, Steel \& Rubenstein, 2010; Richardson, Simmering \& Sturman, 2009; Tourangeau, Rips \& Rasinski, 2000; Doty \& Glick, 1998).

\subsection{Results}

The conceptual model proposed in Figure 1 was tested using SEM. The path coefficients are presented in Figure 2 and Table 5.

First, flexibility had a significant effect on utilitarian value, but it had an insignificant effect on hedonic value. Thus, Hypothesis 1a was accepted while Hypothesis 2a was rejected. Second, results showed that interactivity had a significant effect on perceived utilitarian and hedonic value. Thus, Hypotheses $1 \mathrm{~b}$ and $2 \mathrm{~b}$ were accepted. Finally, results also showed that utilitarian value and hedonic value had a significant effect on satisfaction with e-commerce. Thus, Hypotheses $3 a$ and $3 b$ were also accepted.

FIGURE 2: Results of hypothesis testing

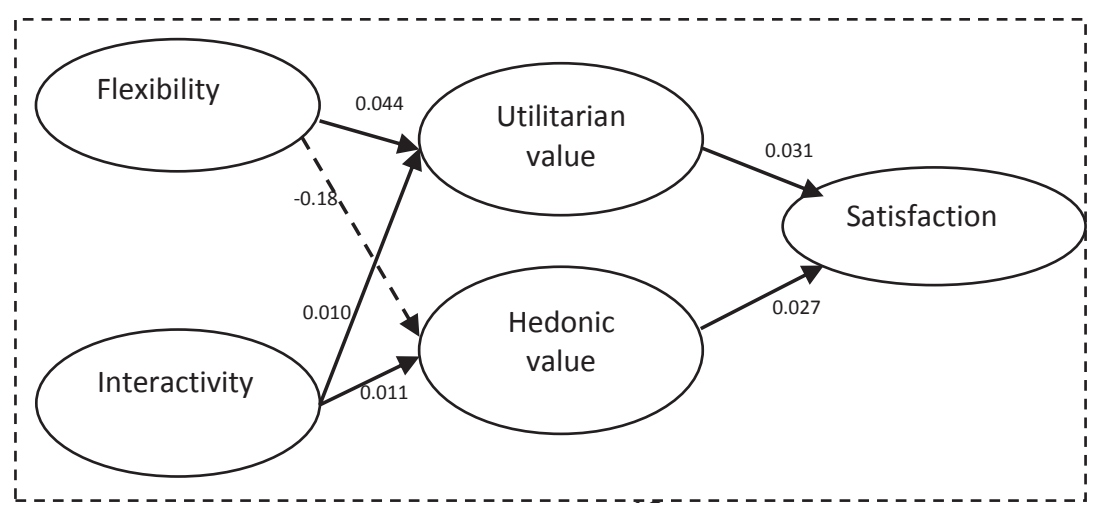

TABLE 5: Hypothesis test

\begin{tabular}{|c|c|c|c|}
\hline Hypotheses & Paths & Estimate & Results \\
\hline $\mathrm{H} 1 \mathrm{a}$ & Flexibility - Utilitarian value & 0.044 & Significant \\
\hline $\mathrm{H} 1 \mathrm{~b}$ & Interactivity - Utilitarian value & 0.010 & Significant \\
\hline $\mathrm{H} 2 \mathrm{a}$ & Flexibility - Hedonic value & -0.18 & Not significant \\
\hline $\mathrm{H} 2 \mathrm{~b}$ & Interactivity - Hedonic value & 0.011 & Significant \\
\hline $\mathrm{H} 3 \mathrm{a}$ & Utilitarian value - Satisfaction & 0.031 & Significant \\
\hline $\mathrm{H} 3 \mathrm{~b}$ & Hedonic value - Satisfaction & 0.027 & Significant \\
\hline
\end{tabular}

Note: ${ }^{*} p<0.05$ 


\section{DISCUSSION}

The purpose of the present study was to analyze the effects of flexibility and interactivity on perceived utilitarian value and hedonic value, and on satisfaction. Results of SEM testing showed that, first, flexibility had a significant effect on the perceived utilitarian value of e-commerce. Second, flexibility had an insignificant effect on the perceived hedonic value of e-commerce. Third, interactivity had a significant effect on the perceived utilitarian value of e-commerce. Fourth, interactivity had a significant effect on the perceived hedonic value of e-commerce. Fifth, perceived utilitarian value and hedonic value had a significant effect on satisfaction in the context of e-commerce. Results were generally consistent with the literature. The literature demonstrates that flexibility and interactivity play an important role in improving consumers' perceived value (Van den Poel \& Leunis, 1999; Bakos, 1997; Alba et al., 1997; Teo et al., 2003; Raney, Arpan, Pashupati \& Brill, 2003).

Results of the present study also support the finding of Yoo and others (2010), Childers and others (2001), Berthon and others (1996), Kim and LaRose (2004), Hoffman and Novak (1996), and Sicilia and others (2005) that flexibility and interactivity are positively associated with utilitarian value but not with hedonic value, that interactivity is positively related to utilitarian value and hedonic value, and that perceived utilitarian and hedonic values are positively related to e-customer satisfaction. This study contributed to the theory in some respects. First, interactivity and flexibility benefit users of e-commerce in accessing and controlling the nature of information on products/services and provide 24-hour comfort, meaning that the two variables are the most important factors in facilitating online transactions (Yoo et al., 2010; Childers et al., 2001; Hoffman \& Novak, 1996; Alba et al., 1997). Second, in the context of e-commerce, perceived value is also considered important with regard to the complementary utilitarian and hedonic benefits for improving users' satisfaction with e-commerce (Overby \& Lee, 2006; To et al., 2007; Yoo et al., 2010; Francis \& White, 2004). This approach provides a clear understanding of the aspects of flexibility and interactivity in e-commerce and the role of each variable in the creation of perceived value and overall satisfaction.

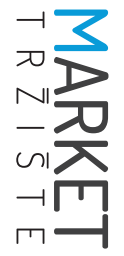

Results of the present study also corroborate those of Childers and others (2001), Yoo and others (2010), and Varadarajan and Yadav (2002), which state that the mutual control over communication is important for maintaining longterm relationships. The present study also found that consumers desire a two-way communication, such as that occurring in off-line transactions; thus, a selection of products/services that require more detailed information can occur. Therefore, there is an increase in variants of products sold online, particularly those that have not previously been sold online, for example, the rental of buildings for various events. The measurement model confirms the two dimensions of common (utilitarian and hedonic) values in the Internet shopping environment and, more importantly, these value dimensions are operationalized at the level of benefits, rather than the level of attributes. This could be the reason why interactivity is less important than flexibility in shaping perceived value, especially hedonic value in the present study, despite the non-unidirectional correlation of flexibility and perceived hedonic value. This is solely due to the fact that consumers who shop specifically for such services as building rental, bridal makeup, hair-cutting services and massage services via e-commerce cannot directly examine in detail the quality they desire in advance. Despite a very attractive design of contents offered by a website, the results could be different from those expected. This was reflected by the profile of respondents in which, of the 415 respondents, only $4 \%$ (18 participants) resort to e-commerce to buy services.

The five paths shown between flexibility and interactivity and consumption value proved significant, whereas one path was not proved significant in the present study. However, a high 


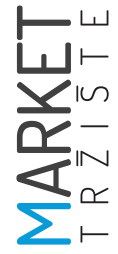

correlation between flexibility and interactivity showed that the variables had a direct effect on perceived value. With regard to the effects of consumption value and satisfaction, utilitarian value had a stronger effect on customer satisfaction than did hedonic value. This study also found that consumers indeed perceived utilitarian and hedonic values to be important values in their preferences for e-commerce use and future intentions, although utilitarian value is a stronger predictor than hedonic value. Offline consumers seemed to turn to the Internet primarily for utilitarian reasons, such as price reduction and convenience. This finding is important since the previous in-store studies (for example, Overby \& Lee, 2006; Yoo et al., 2010; Childers at al., 2001; Babin \& Attaway, 2000; Babin et al., 1994; Batra \& Ahtola, 1991) showed that the dimensions of utilitarian and hedonic values played almost the same role in increasing satisfaction. Given these findings, Internet retailers should ensure that they provide adequate utilitarian values to e-customers before seeking to focus on other aspects of website development.

Therefore, e-tailers have to allocate resources to appropriately combining the qualities of utilitarian and hedonic values proportionately (powerfully and stylishly) in order to increase the overall perceived value. When a company has limited resources, the trade-off of utilitarian value and hedonic value should be considered carefully, such as adding features that are more attractive, easily understood, making it easier for consumers to select products/services, as if transacting offline. This may be done, for example, by adding a live chat that allows customers to communicate directly with retailers and increases the speed of message delivery as a form of e-retailers' service to customers, ultimately leading to an increase in trustworthiness. In the event that a company has to concentrate on a single variable, it must focus on and improve the most basic (utilitarian) service as the most efficient and effective way to improve perceived consumer value.

In order to enhance the two-way dimension of flexibility and interactivity, e-tailers need to add more features of two-way communication, such as a live chat, artificial intelligent agents, and a toll-free call center. In addition, e-tailers should also add features to send messages for frequently asked questions (FAQs), a virtual space such as a blog or a virtual community for its customers to exchange experience with other customers. Consumers spend more time in two-way situations than in browsing information posted, such as FAQs, since flexibility and interactivity add more fun and excitement to their online shopping experience (i.e. creating hedonic value) than one-way communication. However, when such two-way communication tools lead consumers to wait long to communicate with the e-tailer, this will reduce flexibility and interactivity, perceived value and satisfaction. Interactivity can improve perceived utilitarian value due to the speed of communication generated; thus, e-tailers must respond quickly to customers' requests and inquiries, which will ultimately increase customer satisfaction. Server failure or delay in communication throughout the transaction process will undermine flexibility and interactivity significantly. Therefore, each server must be well maintained, and free of hackers' interference.

\section{THEORETICAL AND MANAGERIAL IMPLICATIONS}

In contrast to previous studies, the present study contributes to the existing literature by applying flexibility to e-commerce in order to facilitate e-customer transactions, despite the discussion in previous studies of the importance of interactivity. The findings of this study are different from those of previous studies, explicitly indicating that e-customers require convenience in order to eliminate concerns about trustworthiness, product specifications to obtain more detailed information, and timely delivery of goods (Groß, 2016; Childers et al., 2001; Yoo et al., 2010; Riemer \& Klein, 2001), so consumers prefer to choose e-tailers they trust. However, since the problems 
faced by e-customers concern convenience and trustworthiness, the transaction processing is sometimes regarded as a major barrier to the use of e-commerce; thus, flexibility and interactivity represent new findings in the literature of e-commerce. Results of the present study also show the importance of flexibility and interactivity for making a significant contribution to the creation of perceived value and satisfaction.

In addition to the theoretical implications, several managerial implications can be drawn from the findings of the present study to increase e-customers' perceived values and satisfaction via e-commerce website development. In particular, technical improvements are highly recommended to reduce errors in transaction processing, increase the ease of searching items, improve two-way communication response, shorten the time of delivery of goods purchases, and maintain e-customers' trust; all of which often represent the barriers to consumers' switching from off-line to online transactions, especially in Indonesia where, of the 88 million Internet users, only 27 percent shop via e-commerce (IDC Indonesia, 2015).

\section{LIMITATIONS AND FUTURE RESEARCH}

The present study did not distinguish among the products or services purchased by online consumers, since it only examined the effects of flexibility and interactivity on perceived value and satisfaction in the context of e-commerce in general. Thus, diverse results might be expected if more information was available. For example, information may range from general product/service specifications to the more detailed product/service characteristics, such as those differing from those when purchasing books to desiring to purchase services with more complex specifications, e.g. wedding services and jewelry, barber, masseur service, and bridal makeup. Therefore, future research investigating e-commerce is recommended to gain a deeper insight into the role of flexibility and interactivity with regard to perceived consumption value. For example, e-retailers can add live chats to help provide more detailed information on product/service categories. To define the concept of flexibility and interactivity more efficiently and to comprehend the nature of the concept, a qualitative research approach would be more useful. Quantitative research has a drawback in distinguishing the meaning required to understand this subject (King, 2004). Many studies showed that using a qualitative approach can produce rich, deep, reliable, and revealing explanations (Mayall, 2000; Thaichon \& Quach, 2016).

Value judgment (consumers' assessment of the value) proved to affect preference, satisfaction, loyalty, and other important outcomes (Cronin, Brady \& Hult, 2000). However, most past studies examined the construct in the context of "off-line" consumer behavior, with empirical research in connection with "online shopping" beginning to emerge in the marketing literature more recently. Nevertheless, there are still many unanswered questions, including whether the dimensions of off-line customer values identified by e-tailing literature are equally relevant in the context of online shopping and, if so, the extent to which the differences in the dimensions of these values affect the preference of Internet retailers and future shopping intentions. Future research studies are expected to address these interesting issues.

The present study examined the effect of flexibility and interactivity of e-commerce websites on perceived consumption value by using a sample of consumers in Indonesia. Despite the justification in the literature for using ethnicity- and region-based samples in Indonesia for Internet-related studies, those samples may not reflect the actual overall population of online consumers worldwide. In addition, this study asked the participants to recall their specific online shopping experience. In other words, this study did not conduct a natural experiment with actual online consumers by using interactivity features of online shopping. Thus, the results may not fully reflect what is actually experienced by consumers while shopping online. 


\section{References}

1. Alba, J., Lynch, J., Weitz, B., Janiszewski, C., Lutz, R., Sawyer, A., \& Wood, S., (1997). Interactive home shopping: consumer, retailer, and manufacture incentives to participate in electronic marketplaces. Journal of Marketing, 61(3), 38-53.

2. Anderson, J. C., \& Gerbing, D. W. (1988). Structural equation modeling in practice: a review and recommended two-step approach. Psychology Bulletin, 103, 411-423.

3. Ariely, D. (2000). Controlling the information flow: effects on consumers' decision making and preferences. Journal of Consumer Research, 27(2), 233-248.

4. Auh, S., \& Johnson, M. D. (2005). Compatibility effects in evaluations of satisfaction and loyalty. Journal of Economic Psychology, 26(1), 35-57.

5. Babin, B. J, \& Attaway, J. S. (2000). Atmospheric affect as a tool for creating value and gaining share of customer. Journal Business Research, 49, 91-99.

6. Babin, B. J., Darden, W. R., \& Griffin, M. (1994). Work and/or fun: measuring hedonic and utilitarian shopping value. Journal of Consumer Research, 20(4), 644-656.

7. Bakos, J. Y. (1997). Reducing buyer search costs: implications for electronic marketplaces. Journal Management Science, 43(12), 1676-1692.

8. Banerjee, S., \& Dholakia, R. R. (2013). Situated or ubiquitous? A segmentation of mobile E-shoppers. International Journal Mobile Communication, 11(5), 530-557.

9. Batra, R., \& Ahtola, O. (1991). Measuring the hedonic and utilitarian sources of consumer attitudes. Marketing Letter, 2(2), 159-170.

10. Berthon, P., Pitt, L. F., \& Watson, R. T. (1996). The world wide web as an advertising medium: toward an understanding of conversion efficiency. Journal of Advertising Research, 36(1), 43-54.

11. Bollen, K. A., \& Long, J. S. (1993). Introduction. In: K. A. Bollen \& J. S. Long (Eds.). Testing Structural Equation Models (pp. 1-9). Newbury Park, CA. Sage Publications.

12. Bretz, R. (1983). Media for interactive communication. Beverly Hills, CA: Sage.

13. Browne, M. W., \& Cudeck, R. (1993). Alternative ways of assessing model fit. In: K.A. Bollen \& J. S. Long (Eds.). Testing structural equation models (pp. 136-162). Newbury Park, CA: Sage.

14. Burke, K. (1999). Creating a compelling online experience. CatAge, 16, 109.

15. Burke, R. R. (1997). Do you see what I see? The future of virtual shopping. Journal Academic Marketing Science, 25, 352-360.

16. Büttner, O. B., \& Göritz, A. S. (2007). Perceived trustworthiness of online shops. Journal of Consumer Behaviour, 7(1), 35-50.

17. Byrne, B. M. (1998). Structural equation modeling with LISREL, PRELIS, and SIMPLIS. Basic concepts, applications, and programming. Mahwah, NJ: Lawrence Erlbaum Associates.

18. Childers, T. L., Carr, C. L., Peck, J., \& Carson, S. (2001). Hedonic and utilitarian motivations for online retail shopping behavior. Journal of Retailing, 77(4), 511-535.

19. Chitturi, R., Rajagopal, R., \& Vijay, M. (2008). Delight by design: The role of hedonic versus utilitarian benefits. Journal of Marketing, 72, 48-63.

20. Cho, C-H., \& Leckenby, J. D. (1997). Internet-related programming technology and advertising. Paper presented at the Annual Conference of the American Academy of Advertising, St. Louis, Missouri.

21. Cowles, D. L., Kiecker, P., \& Little, M. W. (2002). Using key informant insights as a foundation for e-tailing theory development. Journal Business Research, 55(8), 629-636.

22. Coyle, J. R., \& Thorson, E. (2001). The effects of progressive levels of interactivity and vividness in web marketing sites. Journal of Advertising, 30(3), 65-77.

23. Crockett, R. O. (2000). Keep 'em coming back. Business Week, 3681: EB20. 
24. Cronin, J. J, Brady, M. K, \& Hult, T. M. (2000). Assessing the effects of quality, value, and information on buyers' product evaluations. Journal Marketing Research, 28, 307-319.

25. Darden, W. R., \& Reynolds F. D. (1971). Shopping orientations and product usage rates. Journal Marketing Research, 8, 505-508.

26. Davis, F. D., Bagozzi, R. P., \& Warshaw, P. R. (1992). Extrinsic and intrinsic motivation to use computers in the workplace. Journal of Applied Social Psychology, 22(14), 1111-1132.

27. Dodds, W. B., Monroe, K. B., \& Grewal, D. (1991). Effect of price, brand, and store information of buyers' product evaluations. Journal Marketing Research, 28, 307-319.

28. Doty, H., \& Glick, W. H. (1998). Common methods bias: Does common methods variance really bias results?. Organizational Research Methods, 1(4), 374-406.

29. Eroglu, S., \& Machliet, K. A. (1990). An empirical study of retail crowding: antecedents and consequences. Journal of Retailing, 66(2), 201-221.

30. Evans, G., Skorpanich, M., Garling, T., Bryant, K., \& Bresolin, B. (1984). The effects of pathway configuration, landmarks, and stress on environmental cognition. Journal of Environmental Cognition, 4, 323-335.

31. Ferri, F., Grifoni, P., \& Guzzo, T. (2013). Factors determining mobile shopping. A theoretical model of mobile commerce acceptance. International Journal Information Process Management, 4(7), 89-101.

32. Fiore, A. M., \& Kim, J. (2007). An integrative framework capturing experiential and utilitarian Shopping Experience. Journal of Retail and Distribution Management, 35(6), 421-442.

33. Fiore, A. M., Kim, J., \& Lee, H. H. (2005). Effect of image interactivity technology on consumer responses toward the online retailer. Journal of Interactive Marketing, 19(3), 38-53.

34. Fornell, C., \& Larker, D. F. (1981). Evaluating structural equation models with unobservable variables and measurement error. Journal Marketing Research, 18, 39-50.

35. Fortin, D. R., \& Dholakia, R. R. (2005). Interactivity and vividness effects on social presence and involvement with a web-based advertisement. Journal of Business Research, 58(3), 387-396.

36. Francis, J. E., \& White, L. (2004). Value across fulfillment product categories of Internet shopping. Managing Service Quality, 14, 226-234.

37. Gao, L., Waechter, K. A., \& Bai, X. (2015). Understanding consumers' continuance intention towards mobile purchase: a theoretical framework and empirical study a case of China. Computer Humanism Behavior, 53(12), 249-262.

38. Geissler, G. L. (2001). Building customer relationships online: the web site designers' perspective. Journal of Consumer Marketing, 18(6), 488-503.

39. Ghose, S., \& Dou, W. Y. (1998). Interactive functions and their impacts on the appeal of internet presences sites. Journal of Advertising Research, 38(2), $29-43$.

40. Grewal, D., Gopalkrishnan, R. I., Krishnan, R., \& Sharma, A. (2003). The Internet and the price value loyalty chain. Journal Business Research, 56(5), 391-398.

41. Groß, M. (2016). Impediments to mobile shopping continued usage intention: A trust-risk-relationship. Journal of Retailing and Consumer Services, 33, 109-119.

42. Guedj, R. A., Hagen, P. J. W., Hopgood, F. R., Tucker, H. A., \& Duce, D. A. (1980). Methodology of interaction. Amsterdam: North Holland Publishing Company.

43. Ha, L., \& James, E. L. (1998). Interactivity reexamined: a baseline analysis of early business web sites. Journal of Broadcasting and Electronic Media, 42(4), 457-469.

44. Hair, J. F., Anderson, R. E., Tatham, R. L., \& Black, W. C. (2010). Multivariate Data Analysis. Delhi: Pearson Education.

45. Hanssen, L., Jankowski, N. W., \& Reinier, E. (1996). Interactivity from the perspective of communication studies. In: N. W. Jankowski \& L. Hanssen (Eds.). The Contours of Multimedia: Recent Technological, Theoretical, and Empirical Developments (pp. 61-73). Luton: University of Luton Press. 
46. Haught, M. J., Wei, R., Xuerui, Y., \& Zhang, J. (2014). Understanding the psychology of mobile phone use and mobile shopping of the 1990s Cohort in China: a lifestyle approach. International Journal Online Marketing, 4(3), 68-84.

47. Hirschman, E. C. (1986). The effect of verbal and pictorial advertising stimuli on aesthetics, utilitarian, and familiarity perceptions. Journal Advertising, 15(2), 27-34.

48. Hirschman, E. C., \& Holbrook, M. B. (1982). Hedonic consumption: emerging concepts, methods, and propositions. Journal of Marketing, 46(3), 92-101.

49. Hofacker, C. F. (2001). Internet Marketing. $3^{\text {rd }}$ ed. New York, NY: John Wiley \& Sons.

50. Hoffman, D. L., \& Novak, T. P. (1996). Marketing in hypermedia computer-mediated environments: conceptual foundations. Journal of Marketing, 60(3), 50-68.

51. Holbrook, M. B. (2005). The nature of customer value: an axiology of service in the consumption experience. In: R. Oliver \& R. T. Rust (Eds.). Service quality: new directions in theory and practice (pp. 21-71). London: Sage Publications.

52. Hoque, A. Y., \& Lohse, G. L. (1999). An information search cost perspective for designing interfaces for electronic commerce. Journal of Marketing Research, 36(3), 387-394.

53. Igbaria, M., Schiffman, S., \& Wieckowski, T. (1994). The respective roles of perceived usefulness and perceived fun in the acceptance of microcomputer technology. Behaviour and Information Technology, 13(6), 349-361.

54. Indonesian E-Commerce Association (2016). The growth of e-commerce Indonesia. https:// www.idea.or.id// (accessed on March, 19 $\left.9^{\text {th }}, 2016\right)$.

55. International Data Corporation Indonesia (2015). Statistical data on growth market share e-commerce in Indonesia. www.idcindonesia.co.id (accessed on June $9^{\text {th }}$, 2016).

56. Jarvenpaa, S. L., \& Todd, P. A. (1997). Consumer reactions to electronic shopping on the World Wide Web. International Journal Electron, 1(2), 59-88.

57. Jensen, J. F. (1998). Interactivity: tracing a new concept in media and communication studies. Nordicom Review, 19(1), 185-204.

58. Kammeyer-Mueller, J., Steel, P. D. G., \& Rubenstein, A. (2010). The other side of method bias: The perils of distinct source research designs. Multivariate Behavioral Research, 45, 294-321.

59. Kim, C., Li, W., \& Kim, D. J. (2015). An empirical analysis of factors influencing M shopping use. International Journal Computer Interactive, 31(12), 974-994.

60. Kim, J., \& LaRose, R. (2004). Interactive e-commerce: promoting consumer efficiency or impulsivity?. Journal of Computer-Mediated Communication, 10(1), 211-219.

61. King, D. A. (2004). The scientific impact of nations. Nature, 4(30), 311-316.

62. Kotler, P., \& Keller, L. K. (2009). Marketing Management. 12 ${ }^{\text {th }}$ ed. New Jersey, NJ: Pearson Education.

63. Liu, Y., \& Shrum, L. J. (2002). What is interactivity and is it always such a good thing? Implications of definition, person, and situation for the influence of interactivity on advertising effectiveness. Journal of Advertising, 31(4), 53-64.

64. Liu, Y. (2003). Developing a scale to measure the interactivity of websites. Journal of Advertising Research, 43(2), 207-216.

65. Lynch, J. G., \& Ariely, D. (2000). Wine online: search costs affect competition on price, quality and distribution. Journal Marketing Science, 19, 83-103.

66. Maddox, R. N. (1982). The structure of consumers' satisfaction: cross-product comparisons. Journal Academic Marketing Science, 10, 37-53.

67. Massey, B. L., \& Levy, M. R. (1999). Interactivity, online journalism, and English- language web newspapers in Asia. Journalism \& Mass Communication Quarterly, 76(1), 138-151.

68. Mathwick, C., Malhotra, N., \& Rigdon, E. (2001). Experiential value: conceptualization, measurement, and application in the catalog and Internet shopping environment. Journal of Retailing, 77(1), 39-56. 
69. Mayall, B. (2000). The sociology of child hood in relation to children's rights. International Journal Children Rights, 8(3), 243-259.

70. McDougall, G. H. G., \& Levesque, T. (2000). Customer satisfaction with services: putting perceived value into the equation. Journal of Services Marketing, 14(5), 392-410.

71. McKnight, D. H., Choudhury, V., \& Kacmar, C. (2002). The impact of initial consumer trust on intentions to transact with a website: a trust building model. Journal of Strategic Information Systems, 11(3/4), 297-323.

72. McMillan, S. J., \& Hwang, J. S. (2002). Measures of perceived interactivity: an exploration of the role of direction of communication, user control, and time in shaping perceptions of interactivity. Journal of Advertising, 37(3), 29-42.

73. McMillan, S. J. (1998). Who pays for content? Funding in interactive media. Journal of Computer Mediated Communication, 4(1), 41-51.

74. McMillan, S. J. (2005). The researchers and the concept: moving beyond a blind examination of interactivity. Journal of Interactive Advertising, 5(1), 22-36.

75. Merrilees, B., \& Fry, M. L. (2003). E-trust: the influence of perceived interactivity on e-retailing users. Marketing Intelligence \& Planning, 21(2), 123-128.

76. Miles, I. (1992). When mediation is the message: how suppliers envisage new markets, computer-mediated communication. In: M. Lea (Ed.). Contexts of Computer-Mediated Communication (pp. 145-167). New York, NY: Harvester-Wheatsheaf.

77. Min, S., \& Mentzer, J. T. (2004). Developing and measuring supply chain management concepts. Journal of Business Logistics, 25(1), 63-99.

78. Mitchell, A. (2000). Why old retail model won't work on the Net. Marketing Week, 23(17), 36-37.

79. Mowen, C. J., \& Minor M. (2002). Consumer Behavior. $9^{\text {th }}$ ed. Boston, MA: Prentice Hall.

80. Novak, T. P., Hoffman, D. L., \& Yung, Y. F. (2000). Measuring the customer experience in online environments: a structural modeling approach. Journal Marketing Science, 19(1), 22-43.

81. Oliver, R. L. (1980). A Cognitive model of the antecedents and consequences of satisfaction decisions. Journal of Marketing Research, 17(11), 460-469.

82. Overby, J. W., \& Lee, E. J. (2006). The Effects of utilitarian and hedonic online shopping value on consumer preference and intentions. Journal Business Research, 59, 1160-1166.

83. Pantano, E., \& Priporas, C. V. (2016). The effect of mobile retailing on consumers' purchasing experiences: a dynamic perspective. Computer Humanism Behavior, 61(8), 548-555.

84. Park, C., Jun, J. K., \& Lee, T. M. (2015). Do mobile shoppers feel smart in the smart phone age?. International Journal Mobile Communication, 13(2), 157-171.

85. Parsons, A. G. (2002). Non-functional motives for online shoppers: why we click. Journal of Consumer Marketing, 19(5), 380-392.

86. Pavlik, J. V. (1998). New media technology: cultural and commercial perspectives. Boston, MA: Allyn and Bacon.

87. Peck, J., \& Childers, T. L. (2000). To have and to hold: the influence of haptic information on product judgments. Working paper, University of Minnesota.

88. Pitta, D., Franzak, F., \& Fowler, D. (2006). A strategic approach to building online customer loyalty: integrating customer profitability tiers. Journal of Consumer Marketing, 23(7), 421-429.

89. Podsakoff, P. M., MacKenzie, S. B., \& Podsakoff, N. P. (2012). Sources of method bias in social science research and recommendations on how to control it. Annual Review of Psychology, 63, 539569.

90. Rafaeli, S. (1988). Interactivity: from new media to communication. In: R. P. Hawkins, J. M. Wiemann \& S. Pingree (Eds.). Advancing communication science: merging mass and interpersonal processes (pp. 110-134). Newbury Park, CA: Sage. 
91. Raney, A. A., Arpan, L. M., Pashupati, K., \& Brill, D. A. (2003). At the movies, on the web: an investigation of the effects of entertaining and interactive web content on site and brand evaluations. Journal of Interactive Marketing, 17(4), 38-53.

92. Ravald, A., \& Gronroos, C. (1996). The value concept and relationship marketing. European Journal of Marketing, 30(2), 19-30.

93. Reio, T. G. (2010). The threat of common method variance bias to theory building. Human Resource Development Review, 9(4), 405-411.

94. Rice, R. E. (1984). New media technology: growth and integration. In: R. E. Rice (Ed.). The New Media: Communication, Research, and Technology (pp. 33-54). Beverly Hills, CA: Sage.

95. Richardson, H. A., Simmering, M. J., \& Sturman, M. C. (2009). A tale of three perspectives: Examining post hoc statistical techniques for detection and correction of common method variance. Organizational Research Methods, 12(2), 762-800.

96. Riemer, K., \& Klein, S. (2001). E-commerce erfordert vertrauen. WISU - Das Wirtsch, 30(5), 710-717.

97. Rosen, K. T., \& Howard, A. L. (2000). E-retail: gold rush or fool's gold?. California Management Review, 42, 72-100.

98. San-Martín, S., \& López, C. B. (2013). How can a mobile vendor get satisfied customers?. Management Data System, 113(2), 156-170.

99. Segars, A. H., \& Grover, V. (1993). Re-examining perceived ease of use and usefulness: a confirmatory factor analysis. MIS Quarterly, 17(4), 517-527.

100. Sheth, J. N., Newman, B. I., \& Gross, B. L. (1991). Consumption values and market choice. Cincinnati, $\mathrm{OH}$ : South Western Publishing.

101. Sicilia, M., Ruiz, S., \& Munuera, J. L. (2005). Effects of interactive in a web site: the moderating effect of need for cognition. Journal of Advertising, 34(3), 31-45.

102. Sohn, S. (2014). Warum smart phone-Nutzernicht mobile inkaufen. Marketing Review Gallery Die neue Thexis, 31(5), 32-41.

103. Spector, P. E. (1987). Method variance as an artifact in self-reported affect and perceptions at work: Myth or significant problem?. Journal of Applied Psychology, 72, 438-443.

104. Steuer, J. (1992). Defining virtual reality: dimensions determining telepresence. Journal of Communication, 42(4), 73-93.

105. Stewart, D. W., \& Pavlou, P. A. (2002). From consumer response to active consumer: measuring the effectiveness of interactive media. Journal of the Academy of Marketing Science, 30(4), 376396.

106. Straubhaar, J., \& LaRose, R. (1996). Communications media in the information society. Belmont, CA: Wadsworth Press.

107. Stromer-Galley, J. (2000). Online interaction and why candidates avoid it. Journal of Communication, 50(4), 111-132.

108. Sundar, S. S., \& Kim, J. (2005). Interactivity and Persuasion: influencing attitudes with information and involvement. Journal of Interactive Advertising, 5(2), 215-227.

109. Swinyard, W. R, \& Smith, S. M. (2003). Why people (don't) shop online: a lifestyle study of the Internet consumer. Psychol Marketing Journal, 20(7), 567-597.

110. Teo, H. H., Oh, L. B., Liu, C., \& Wei, K. K. (2003). An empirical study of the effects of interactivity on web user attitude. International Journal of Human Computer Studies, 58(3), 281-305.

111. Thaichon, P., \& Sara, Q. (2016). Dark motives-counterfeit purchase framework: Internal and external motives behind counterfeit purchase via digital platforms. Journal of Retailing and Consumer Services, 33, 82-91.

112. Thaichon, P., \& Quach, T. N. (2016). Online marketing communications and childhood's intention to consume unhealthy food. Australia Marketing Journal, 24(1), 79-86. 
113. Titus, P. A., \& Everett, P. B. (1995). The consumer retail search process: a conceptual model and research agenda. Journal of the Academy of Marketing Science, 23(2), 106-119.

114. To, P. T., Chechen, L., \& Lin, L. H. (2007). Shopping motivations on Internet: A study based on utilitarian and hedonic value. Journal of Technovation, 27, 774-787.

115. Tourangeau, R., Rips, L. J., \& Rasinski, K. (2000). The psychology of survey response. Cambridge University Press: Cambridge.

116. Unger, L. S, \& Kernan, J. B. (1983). On the measuring of leisure: an investigation of some determinants of the subjective experience. Journal Consumer Research, 9, 381-391.

117. Van den Poel, D., \& Leunis, J. (1999). Consumer acceptance of the internet as a channel of distribution. Journal of Business Research, 45(3), 249-256.

118. Van Dijk, J. (1999). The Network Society: Social Aspects of New Media. Thousand Oaks, CA: Sage.

119. Varadarajan, P. R., \& Yadav, M. S. (2002). Marketing strategy and the internet: an organizing framework. Journal of the Academy of Marketing Science, 30(4), 296-312.

120. Vor dem Esche, J., \& Hennig-Thurau, T. (2014). German digitalization consumer report, Research Report No. 2. Available at: https://www.rolandberger.de/media/pdf/Roland_Berger_German_ Digitalization_Consumer_Report_20140718.pdf (accessed on July 16 $\left.{ }^{\text {th }}, 2016\right)$.

121. Wang, R. J. H., Malthouse, E. C., \& Krishnamurthi, L. (2015). On the Go: how mobile shopping affects customer purchase behavior. Journal Retaling, 91(2), 217-234.

122. Weisman, G. (1981). Evaluating architectural legibility: way finding in the built environment. Environment and Behavior, 13(2), 189-204.

123. Wiener, N. (1948). Cybernetics, or Control and Communication in the Animal and The Machine., Cambridge, MA: Technology Press.

124. Williams, L. J., \& Anderson, S. E. (1994). An alternative approach to methods effects by using latent-variable models: Applications in organizational behavior research. Journal of Applied Psychology, 79, 323-331.

125. Woodruff, R. B. (1997). Customer value: the nest source for competitive advantage. Journal of the Academy of Marketing Science, 25(2), 139-154.

126. Woodruff, R. B. (1997). Customer value: the next source for competitive advantage. Journal Academic Marketing, 25, 139-153.

127. $\mathrm{Wu}, \mathrm{G}$. (2005). The mediating role of perceived interactivity in the effec to factual interactivity on attitude toward the website. Journal of Interactive Advertising, 5(2), 29-39.

128. Yadav, M. S., \& Varadarajan, P. R. (2005). Interactivity in the electronic marketplace: an exposition of the concept and implications for research. Journal of the Academy of Marketing Science, 33(4), 585-603.

129. Yang, S., Chen, Y., \& Wei, J. (2015). Understanding consumers' web-mobile shopping extension behavior: a trust transfer perspective. Journal Computer Information System, 55(2), 78-87.

130. Yoo, W. S., Yunjung, L., \& Jung, K. P. (2010). The role of interactivity in e-tailing: Creating value and increasing satisfaction. Journal of Retailing and Consumer Services, 17, 89-96.

131. Zack, M. H. (1993). Interactivity and communication mode choice in ongoing management groups. Journal Information Systems Research, 4(3), 207-239.

132. Zeithaml, V. A. (1988). Consumer perceptions of price, quality and value: a means end model and synthesis of evidence. Journal of Marketing, 52(3), 2-22.

133. Zeithaml, V. A., Parasuraman, A., \& Malhotra, A. (2002). Service quality delivery through web sites: a critical review of extant knowledge. Journal of the Academy of Marketing Science, 30(4), 362-375. 